\title{
Pengembangan Kurikulum Kewirausahaan di Sekolah Menengah Pertama
}

\author{
Yudha Nata Saputra \\ Program Studi Pendidikan Agama Kristen, STT Kharisma \\ e-mail: yudhanata@yahoo.com
}

\begin{abstract}
Abstrak: Tujuan penulisan artikel ini dimaksudkan untuk mengkaji pengembangan kurikulum kewirausahaan di SMP yang berkaitan dengan definisi kurikulum kewirausahaan, landasan penyusunan kurikulum kewirausahaan, desain pengembangan kurikulum kewirausahaan dan nilai-nilai kewirausahaan yang dimuat dalam kurikulum kewirausahaan. Pengembangan kurikulum kewirausahaan menjadi sesuatu yang penting dalam rangka mengurangi pengangguran di negeri dan meningkatkan kemakmuran rakyat. Tingkat SMP merupakan tempat yang strategis untuk pengembangan kurikulum kewirausahaan karena pada tahap perkembangan ini, siswa sudah memiliki kemampuan berpikir yang lengkap sehingga amat potensial untuk mereka bisa menyerap dan menerapkan nilai-nilai kewirausahaan dalam pengalaman belajar mereka.
\end{abstract}

Kata kunci: kurikulum, wirausaha, orientasi, dan nilai.

\begin{abstract}
The purpose of writing of this article is to analysis of entrepreneurship in junior high school curriculum development related to the definition of entrepreneurship curriculum, the foundation of entrepreneurship curriculum design, curriculum development in entrepreneurship and entrepreneurial values contained in the curriculum of entrepreneurship. Developing entrepreneurship curriculum into something that is important in order to reduce unemployment in the country and improve people's welfare. Junior high school is a strategic place for the development of entrepreneurship curriculum because at this developmental stage, students already have the ability to think is so very full of potential for them to absorb and apply the values of entrepreneurship in their learning experience.
\end{abstract}

Key words: curriculum, entrepreneurship, orientation, and values.

\section{Pendahuluan}

Salah satu masalah yang dihadapi oleh negara berkembang seperti Indonesia adalah tingginya tingkat pengangguran. Catatan Kementerian Pendidikan Nasional pada tahun 2010 menunjukkan bahwa dari 14 juta sarjana yang tercatat saat ini, 2 juta diantaranya menjadi pengangguran (Kompas.com, 27/9/2010).
Sementara itu jumlah wirausahawan yang dimiliki oleh Indonesia saat ini hanya sekitar 0,24\%, jumlah ini masih sangat jauh jika dibandingkan dengan negara Singapura 7\% dan Malaysia 5\% (Antaranews.com, 26/1/2011). Rendahnya minat untuk berwirausaha juga ditunjukkan oleh data di bawah ini:

\begin{tabular}{|l|c|c|c|c|c|c|}
\hline \multirow{2}{*}{$\begin{array}{c}\text { Tingkat } \\
\text { Pendidikan }\end{array}$} & $\begin{array}{l}\text { Mandiri } \\
(\%)\end{array}$ & $\begin{array}{l}\text { Buruh/K } \\
\text { aryawan } \\
(\%)\end{array}$ & $\begin{array}{l}\text { Dibantu } \\
\text { buruh ti- } \\
\text { dak tetap } \\
(\%)\end{array}$ & $\begin{array}{l}\text { Pekerja } \\
\text { bebas } \\
(\%)\end{array}$ & $\begin{array}{l}\text { Dibantu } \\
\text { buruh } \\
\text { tetap(\%) }\end{array}$ & $\begin{array}{l}\text { Pekerja } \\
\text { Keluarga(\%) }\end{array}$ \\
\hline $\begin{array}{l}\text { Tidak/Belum } \\
\text { tamat SD }\end{array}$ & 20.07 & 14.98 & 1.49 & 22.56 & 12.22 & 28.67 \\
\hline SD/MI & 19.71 & 13.52 & 1.78 & 28.59 & 9.87 & 26.53 \\
\hline SMP/MTs & 18.8 & 10.3 & 2.03 & 39.2 & 62.3 & 23.44 \\
\hline SMA/MA & 15.13 & 7.5 & 2.55 & 60.87 & 2.26 & 11.69 \\
\hline PT & 6.14 & 3.28 & 3.12 & 83.18 & 0.35 & 3.98 \\
\hline
\end{tabular}

Sumber:Suderadjat (2010) 
Berdasarkan tabel di atas bisa dilihat bahwa justru dengan semakin tinggi tingkat pendidikan tidak serta merta meningkatkan jumlah wirausahawan malah sebaliknya keinginan untuk hidup mandiri menjadi semakin rendah. Hal ini bisa dilihat dari orientasi kebanyakan lulusan perguruan tinggi di Indonesia yang lebih mengutamakan untuk mencari pekerjaan setelah lulus dibandingkan dengan mereka berusaha untuk membuka lapangan kerja sendiri.

Rendahnya jumlah wirausaha yang dimiliki Indonesia tentunya akan berpengaruh terhadap tingkat pengangguran dan pendapatan perkapita, yang jika terus dibiarkan akan menghambat citacita bangsa Indonesia untuk mencapai kesejahteraan dan kemakmuran sebagaimana yang diamanatkan dalam pembukaan UUD'45.

Dalam rangka mengatasi meningkatkan kemandirian lulusan pendidikan di Indonesia maka kewirausahaan memegang peranan penting karena ketika berbicara tentang kemandirian maka kita sedang berbicara tentang kewirausahaan. Kewirausahaan sendiri secara harafiah dapat diartikan sebagai keberanian, ketauladanan dalam berusaha. Robin \& Coulter (dalam Putra, 2008) mengatakan bahwa:

Entrepreneurship is the process whereby an individual or a group of individuals uses organized efforts and means to pursue opportunities to create value and grow by fulfilling wants and need through innovation and uniqueness, no matter what resources are currently controlled Definsi kewirausahaan di atas menunjukkan bahwa untuk mampu mengorganisasi sumber daya yang mampu menciptakan nilai, inovasi dan keunikan maka seseorang harus memiliki kemandirian, tidak bergantung kepada orang lain dan bisa menciptakan sesuatu yang baru. Berdasarkan definisi kewirausahaan di atas maka bisa dikatakan bahwa seorang wirausahawan tidak bergantung kepada sumber daya tapi sebaliknya ia mampu mengontrol sumber daya dan mempergunakannya untuk menciptakan sesuatu. Dengan demikian orisinalitas menjadi kunci dari kewirausahaan dan orisinalitas dicapai jika seseorang memiliki kemandirian dalam berpikir yang akan menghasilkan inovasi.

Dalam rangka mengatasi persoalan tingginya pengangguran di Indonesia maka perlu kewira- usahaan dijadikan salah satu muatan kurikulum di SMP. Pendidikan dasar dalam hal ini menjadi tempat yang potensial untuk menerapkan kurikulum kewirausahaan berdasarkan beberapa alasan. Pertama, dari sisi psikologi perkembangan, peserta didik di tingkat SMP sudah memiliki kemampuan berpikir yang lengkap jika dibandingkan dengan SD. Kedua, semakin dini pendidikan kewirausahaan diperkenalkan maka akan semakin bermanfaat karena proses penyerapan nilai-nilai membutuhkan waktu. Ketiga, jenjang pendidikan dasar merupakan pemasok tenaga kerja yang cukup besar dibandingkan jenjang pendidikan lain, 71,69\% angkatan kerja kita didominasi oleh lulusan SLTP ke bawah (Depdiknas, 2009). Keempat, program wajar sembilan tahun menuntut sekolah untuk membekali siswa dengan life skill sehingga setelah lulus siswa memiliki kemampuan untuk hidup mandiri.

Berdasarkan latar belakang di atas maka rumusan masalah dalam tulisan ini sebagai berikut: 1) Definisi kurikulum seperti apa yang akan digunakan untuk menerapkan kurikulum kewirausahaan? 2) Apa saja landasan kurikulum yang digunakan untuk mengembangkan kurikulum kewirausahaan? 3) Jenis desain kurikulum seperti apa yang bisa digunakan dalam pengembangan kurikulum kewirausahaan? 4) Nilai-nilai kewirausahaan apa saja yang ada dalam muatan kurikulum kewirausahaan?

Adapun tujuan dari tulisan ini yaitu untuk mengkaji tentang pengembangan kurikulum kewirausahaan di SMP yang berkaitan dengan definisi kurikulum kewirausahaan, landasan penyusunan kurikulum kewirausahaan, desain pengembangan kurikulum kewirausahaan dan nilai-nilai kewirausahaan yang dimuat dalam kurikulum kewirausahaan.

\section{Kajian Literatur dan Pembahasan Definisi Kurikulum Kewirausahaan}

Kurikulum senantiasa mengalami perkembangan sesuai dengan definisi yang dikembangkannya. Awalnya istilah kurikulum digunakan dalam lingkungan olahraga yang diartikan sebagai suatu jarak yang harus ditempuh oleh seorang pelari. Seiring dengan perkembangan waktu istilah kurikulum pun mengalami perkembangan, di 
bawah ini beberapa definisi kurikulum yang dikemukakan oleh beberapa ahli (Nasution, 2006), yaitu: 1) The Curriculum is the sum total of school's efforts to influence learning, whether in the clasroom, on the playground, or out of school (J. Galen Saylor dan William M. Alexander, th 1981); 2) "All of the activities that are provided for students by the school" (Harold B. Alberty, 1965); 3) "a sequence of potential experiences set up in the school for the purpose of disciplining children and youth in group ways of thinking and acting" (B. Othanel Smith, 1955); 4) The tendency in recent decades has ben to use the term in a broader sense to refer to the whole life and program of the school. The term is used ... to include all the experiences of children for which the school accepts responsibility. It denotes the results of efferorts on the part of the adults of the community, and the nation to bring to the children the finest, most whole some influences that exists in the culture" (William B. Ragan, 1955); dan 5) "A curriculum consists of the means used to achieve or carry out given purposes of schooling" (Edward A. Krug, 1960).

Berdasarkan definisi kurikulum di atas bisa dilihat bahwa lingkup kurikulum berbeda satu sama lain, ada yang mengartikannya sebagai sejumlah pengalaman, kegiatan baik dalam lingkup sekolah maupun di luar sekolah. Beragamnya pengertian kurikulum ini sesuai dengan yang dikatakan oleh Henderson, et. al (2000) bahwa seperti istilah-istilah lain dalam pendidikan, kurikulum merupakan sebuah konsep yang komplek, ketika orang menggunakan istilah kurikulum maka kita tidak dapat mengetahuinya sampai mereka menjelaskannya.

Wirausaha berasal dari dua kata yaitu wira yang berarti berani, tauladan sedangkan usaha diartikan sebagai pekerjaan. Dengan demikian, secara harafiah wirausaha adalah pekerjaan yang dimulai dengan keberanian atau pekerjaan yang memberikan teladan. Letak keberanian dari seorang wirausaha diwujudkannya dengan kemampuannya untuk menanggung risiko yang terukur dalam rangka mewujudkan suatu kesuksesan sekaligus keberanian itu adalah sesuatu yang menjadi teladan. Selain berbicara keberanian dan keteladanan, perspektif yang tak kalah penting dari seorang wirausahawan yaitu kemandirian dan kemampuannya untuk menye- lesaikan masalah yang juga patut diteladani. Beberapa ahli berusaha mendefinisikan kewirausahaan sebagai berikut: 1) Joseph Schumpeter (dalam Hermana, 2008) mengemukakan bahwa wirausahawan adalah seorang inovator yang mengimplementasikan perubahanperubahan di dalam pasar melalui kombinasikombinasi baru; 2) Kemampuan untuk menciptakan sesuatu yang baru dan berbeda "ability to create the new and different", Peter F Drucker (dalam Putra, 2008); 3) Thomas W Zimmerer (dalam Putra, 2008) mengatakan bahwa kewirausahaan adalah penerapan kreativitas dan keinovasian untuk memecahkan permasalahan dan upaya memanfaatkan peluang-peluang yang dihadapi orang setiap hari; dan 4) Raymond (dalam Lupiyoadi dan Wajik, 1998) berpendapat bahwa entrepreneurship merupakan proses penciptaan sesuatu yang baru atau inovasi guna memperoleh kesejahteraan atau kekayaan individu dan mendapatkan nilai tambah bagi masyarakat.

Melihat beberapa definisi kewirausahaan di atas maka bisa dikatakan bahwa kewirausahaan itu berkaitan dengan proses berpikir yang kreatif dan inovatif dari seseorang yang dilakukan untuk mencapai suatu keberhasilan. Jika melihat berbagai definisi kurikulum dan kewirausahaan di atas maka kurikulum kewirausahaan dapat didefinisikan bermacam-macam, kurikulum kewirausahaan dapat diartikan sebagai program kewirausahaan yang dapat berbentuk mata pelajaran kewirausahaan, kegiatan kewirausahaan atau pengalaman kewira-usahaan yang membekali siswa dengan kemampuan berpikir inovatif dan kreatif untuk memecahkan berbagai persoalan yang dihadapinya.

\section{Landasan Pengembangan Kurikulum Kewirausahaan}

Dalam mengembangkan kurikulum kewirausahaan terdapat sejumlah asas yang perlu dikaji agar kurikulum yang disusun bisa tepat kepada sasaran, bermanfaat dan cocok diterapkan dalam kehidupan. Nasution (2006) mengemukakan empat landasan kurikulum yang perlu diperhatikan yaitu asas filosofis, asas psikologis, asas sosiologis dan asas organisatoris. Adapun landasan pengembangan kurikulum kewirausahaan dapat dijabarkan sebagai berikut. 
Pertama, asas filosofis pengembangan kurikulum kewirausahaan adalah kemandirian. Kemandirian adalah sesesuatu yang amat berharga bagi bangsa Indonesia. Semangat juang bangsa Indonesia yang menginginkan kemerdekaan menunjukkan bahwa kehidupan yang mandiri itu adalah lebih baik daripada bergantung kepada orang lain. Kenyataan ini juga ditunjang dengan salah satu cita-cita bangsa Indonesia agar masyarakatnya bisa hidup dengan sejahtera dan sejajar dengan bangsa-bangsa lain turut melandasi perlunya dikembangan kurikulum kewirausahaan.Dalam keyakinan agama-agama di Indonesia juga meyakini bahwa kemandirian adalah sesuatu yang penting "tangan di atas lebih baik daripada tangan di bawah", membantu orang lain dengan usaha yang dilakukan adalah sesuatu yang dihargai dalam kontek masyarakat Indonesia karena mereka memiliki pola budaya hidup bergotong royong dan kekeluargaan. Kedua, asas psikologis pengembangan kurikulum kewirausahaan berkenaan dengan psikologi anak dan psikologi belajar. Psikologi anak berbicara tentang minat dan kebutuhan anak dalam setiap tahap perkembangannya sedangkan psikologi belajar menyoroti bagaimana seseorang belajar. Kedua asas psikologi ini penting karena akan membantu dalam menyusun bahan dan metode yang cocok digunakan dalam kurikulum kewirausahaan. Ketiga, asas sosiologis pengembangan kurikulum kewirausahaan adalah perubahan masyarakat, setiap saat masyarakat selalu berkembang baik tuntutan maupun norma-norma yang dianutnya sehingga kurikulum yang dibentuk diharapkan bisa memenuhi tuntutan masyarakat sebaliknya tidak malah membuat seseorang terasing dari kehidupan masyarakat. Persoalan pengangguran dan rendahnya pendapatan perkapita yang berimbas kepada kemiskinan menuntut sekolah untuk memperlengkapi siswa dengan kemampuan untuk berwirausaha. Di samping itu, dengan situasi yang semakin komplek juga menuntut sekolah membekali siswa dengan kemampuan untuk mampu memecahkan masalah. Keempat, asas organisatoris pengembangan kurikulum kewirausahaan, berbicara tentang bagaimana bahan pelajaran dalam kurikulum kewirausahaan akan disajikan. Dilihat dari penyajiannya pengembangan kurikulum kewirausahaan dapat disajikan dalam tiga bentuk yaitu SeparatedSubject Curriculum, Correlated Curriculum dan Integrated Curriculum.Pengembangan kurikulum kewirausahaan yang berbentuk Separated-Subject Curriculum dilakukan dengan menyajikan kurikulum kewirausahaan sebagai pelajaran tersendiri yang tidak berkaitan dengan mata pelajaran lainnya. Pengembangan kurikulum kewirausahaan yang berbentuk Correlated Curriculum dilakukan dengan menghubungkan mata pelajaran kewirausahaan dengan mata pelajaran lainnya. Pengembangan kurikulum kewirausahaan yang berbentuk Integrated Curriculum dilakukan dengan mengintegrasikannya ke dalam setiap kegiatan belajar siswa di sekolah.

\section{Desain Pengembangan Kurikulum Kewirausahaan}

Desain pengembangan kurikulum berbicara tentang model kurikulum yang dikembangkan sesuai dengan aliran-aliran pendidikan yang berkembang. Ada empat model kurikulum yang berkembang saat ini (Sukmadinata, 2008) yaitu: 1) Kurikulum Subjek Akademis, kurikulum subjek akademis dikembangkan sesuai dengan fungsi sekolah sebagai pemelihara nilai. Tujuan dari kurikulum ini yaitu menguasai ilmu sebanyakbanyaknya; 2) Kurikulum Humanistik, kurikulum ini dikembangkan sesuai dengan fungsi sekolah untuk mengoptimalkan potensi peserta didik secara menyeluruh; 3) Kurikulum Rekonstruksi Sosial, kurikulum ini dikembangkan berdasarkan keprihatinan terhadap masalah-masalah sosial yang terjadi di masyarakat. Sekolah sebagai organisasi yang ada di masyarakat juga merupakan bagian dari masyarakat sehingga harus menyumbangkan sesuatu yang berguna bagi masyarakat; dan 4) Kurikulum Teknologis, perkembangan teknologi yang terus berkembang mengharuskan manusia untuk menguasainya jika tidak ingin ketinggalan, kurikulum teknologis pada dasarnya dikembangkan dari kurikulum subjek akademik namun dengan tekanan yang berbeda. Jika subjek akademik ditekankan pada pengawetan pengetahuan maka kurikulum teknologis menekankan kepada penguasaan kompetensi.

Dengan melihat keempat desain kurikulum di atas maka kurikulum kewirausahaan dapat 
dikembangkan dengan tujuan untuk melestarikan nilai-nilai kewirausahaan, mengembangkan potensi kewirausahaan yang dimiliki oleh siswa, memecahkan persoalan yang terjadi di masyarakat dan usaha untuk membekali siswa dengan kemampuan untuk berwirausaha.

\section{Muatan Kurikulum Kewirausahaan}

Mengingat besarnya perananan wirausahawan dalam mendayagunakan sumber daya sehingga bisa meningkatkan pendapatan ekonomi telah membuat banyak pihak tertarik untuk meneliti proses terbentuknya wirausahawan. Sampai dengan saat ini terdapat beberapa teori yang berusaha untuk menjelaskan proses terbentuknya wirausaha yaitu: 1) Teori Life Path change, Shapero dan Sokol (dalam Lucas, 2007) mengatakan bahwa pilihan menjadi wirausahawan tidak terjadi secara disengaja tapi karena suatu desakan dari peristiwa yang tidak direncanakan; 2) Teori Goal Directed Behavior, menurut Wolman (dalam Wardoyo, 2008) seseorang menjadi wirausahawan karena termotivasi oleh tujuan tertentu. Kebutuhan adalah titik tolak utama dari kegiatankegiatan yang melandasi suatu tujuan untuk mempertahankan dan memperberbaiki kelangsungan hidup; 3) Teori Outcome Expectancy, teori ini dibangun atas dasar keyakinan bahwa seseorang akan mampu meraih hasil yang diinginkannya jika ia melakukan perilaku tertentu. Seorang yang menganggap bahwa dengan berwirausaha akan memberikan hasil yang sesuai dengan keinginannya akan berusaha untuk menjadi wirausahawan. Insentif yang diharapkan seseorang dalam hal ini bisa bermacam-macam antara lain: a) memenuhi kebutuhan makan, minum/fisiologis; b) mendapatkan penghargaan; c) mencukupi kebutuhan ekonomi; d) memberikan kekuasaan, dan e) memberikan rasa puas.

Meskipun terbentuknya seorang wira-usahawan bisa terjadi melalui proses yang berbedabeda namun terdapat ciri-ciri yang membedakan antara seorang wirausahawan dengan orang biasa. Gooffrey G. Meredith (dalam Susanti, 2008) mengemukakan tujuh ciri yang melekat kepada wirausahawan: 1) Percaya diri; 2) Berorientasi kepada tugas dan hasil; 3) Berani mengambil risiko; 4) Kepemimpinan; 5) Keorisinilan; 6) Berorientasi ke depan; dan 7) Jujur dan tekun.
Selanjutnya, Permana (2008) mengemukakan lima tindakan seorang wirausahawan: 1) Aktif mencari perubahan dengan membaca berbagai peluang; 2) Berani menanggung dan mengendalikan risiko; 3) Cenderung menerima kesalahan sebagai sesuatu yang wajar; 4) Didorong oleh kebebasan dan peluang untuk memperoleh keuntungan finansial; dan 5) Lebih langsung dan intensif terlibat dalam aktivitas operasional organisasi.

Adapun M. Scarborough dan Thomas W. Zimmerer (dalam Susanti, 2008) mengemukakan bahwa ada delapan karakteristik wirausahawan: 1) Bertanggung jawab akan tugas; 2) Memilih risiko moderat (terukur); 3) Percaya kepada kemampuannya; 4) Menginginkan umpan balik yang segera; 5) Berorientasi ke depan; 6) Bekerja keras untuk hasil lebih baik; 7) Memiliki keterampilan mengorganisasikan sumber daya; dan 8) Menilai prestasi dengan uang.

Dengan melihat paparan di atas bisa dilihat bahwa tindakan seorang wirausaha senantiasa dilandasi oleh nilai-nilai tertentu yang membawanya kepada keberhasilan dalam melakukan pekerjaannya, nilai-nilai kewirausahaan itulah yang bisa dijadikan muatan dalam pengembangan kurikulum kewirausahaan

\section{Pembahasan \\ Pengembangan Kurikulum Kewirausahaan di Sekolah Menengah}

Pendidikan formal di Indonesia terbagi ke dalam tiga jenjang pendidikan, pendidikan dasar, menengah dan tinggi. Jenjang pendidikan dasar meliputi SD dan MI dilanjutkan dengan SMP dan MTs. Jenjang pendidikan menengah meliputi SMA, MA, SMK dan MAK. Jenjang pendidikan tinggi meliputi diploma, sarjana, magister, spesialis dan doktor.

Jenjang pendidikan dasar memegang peranan yang penting dalam sistem pendidikan karena menjadi landasan menuju jenjang pendidikan berikutnya, semakin baik kualitas pendidikan dasar akan menenentukan keberhasilan siswa di jenjang pendidikan selanjutnya maupun keberhasilan siswa dalam menempuh kehidupan nyata di masyarakat. Berkenaan dengan penanaman nilai-nilai kewirausahaan maka akan sangat baik jika bisa ditanamkan sejak 
dini yang disesuaikan dengan taraf perkembangan anak.

Siswa usia SMP adalah siswa dengan ratarata usia 12 tahun yang sudah memiliki kemampuan berpikir yang lengkap jika dibandingkan dengan siswa di tingkat SD sehingga kurikulum kewirausahaan akan bisa diterapkan dengan optimal sejak anak berada di jenjang SMP. Anakanak di usia 12 tahun ke atas sudah berada pada tahap berpikir operasi formal yang memiliki ciriciri sebagai berikut Flavell (1963): a) Memiliki pola berpikir hypotetico-deductive. Mereka telah dapat membuat hipotesis-hipotesis dari suatu problema dan membuat keputusan terhadap problema itu secara tepat, tetapi anak kecil belum dapat menyimpulkan apakah hipotesisnya ditolak atau diterima; b) Berada pada periode propositional thinking. Remaja telah dapat memberikan statemen atau proposisi berdasar pada data yang konkret. Meskipun kadang-kadang ia masih berhadapan dengan proposisi yang bertentangan dengan fakta; c) Berada pada periode combinational thinkin. Jika remaja mempertimbangkan tentang pemecahan problem maka ia telah dapat memisahkan faktor-faktor yang menyangkut dirinya dan mengombinasi faktor-faktor tersebut.

Melihat karakteristik siswa SMP yang sudah mampu mengindentifikasi masalah, menyusun hipotesis, menginterpretasi data dan memecahkan masalah secara obyektif maka kurikulum kewirausahaan di jenjang SMP akan lebih tepat jika disajikan dalam bentuk program yang dituangkan dalam bentuk kegiatan-kegiatan pembelajaran yang memberikan pengalaman kepada siswa dalam menerapkan nilai-nilai kewirausahaan dibandingkan dengan membuatnya sebagai mata pelajaran tersendiri. Hal ini juga didukung dengan kenyataan masih cukup padatnya muatan kurikulum saat ini, muatan kurikulum SMP saat ini terdiri dari 10 mata pelajaran di luar komponen muatan lokal dan pengembangan diri dengan jumlah jam secara keseluruhan 32 jam perminggu.

Dengan mengganggap kurikulum kewirausahaan sebagai program yang berisi kegiatankegiatan yang memberikan pengalaman kepada siswa untuk menyerap nilai-nilai kewirausahaan maka di samping hal itu tidak akan terlalu membebani kurikulum sebaliknya juga akan memberikan cakupan yang lebih luas karena akan bisa mewarnai semua kegiatan pembelajaran di sekolah baik itu yang dilaksanakan di dalam kelas maupun kegiatan pembelajaran di luar kelas.

Melalui berbagai kegiatan yang diintegrasikan dalam kegiatan pembelajaran di sekolah maka diharapkan di dalam setiap mata pelajaran nantinya akan ada aktivitas-aktivitas yang memberikan kesempatan kepada siswa untuk memperoleh pengalaman dalam menyerap dan menerapkan nilai-nilai kewirausahaan. Contoh dalam mata pelajaran Bahasa Indonesia, siswa diminta untuk membuat pantun. Melalui kegiatan ini siswa dituntut untuk berpikir kreatif dan inovatif yang menjadi salah satu ciri dari kewirausahaan.

Contoh lain, seorang siswa dihadapkan pada suatu situasi dimana ada salah satu rekannya yang kehilangan uang sehingga tidak memiliki ongkos untuk pulang maka siswa tersebut akan dihadapkan pada suatu pilihan, untuk membantunya dengan cara menyisihkan uang jajan atau tidak membantunya. Di sini siswa harus menimbang risiko atas keputusannya, membantunya berarti ia harus menyisihkan uang jajan yang berarti siswa tersebut harus mengurangi pengeluaran untuk jajan atau tidak membantunya sehingga ia tidak perlu mengurangi jatah jajannya. Melalui contoh tadi bisa dilihat bahwa praktek dari kurikulum kewirausahaan tidak harus melulu dipraktekkan dalam mata pelajaran namun bisa juga diterapkan dalam berbagai situasi nyata di luar kegiatan pembelajaran di kelas.

Adapun desain kurikulum kewirausahaan yang akan dikembangkan dalam kurikulum kewirausahaan ini pada dasarnya adalah kurikulum rekonstruksi sosial. Hal ini sesuai dengan kenyataan bahwa pentingnya mengembangkan kurikulum kewirausahaan di sekolah berkenaan dengan masalah rendahnya jiwa kewirausahaan yang dimiliki oleh lulusan lembaga pendidikan yang kemudian mengakibatkan tingginya tingkat pengangguran di Indonesia.

Tujuan dari kurikulum kewirausahaan yang dikembangkan di SMP ini yaitu untuk memecahkan persoalan pengangguran yang ada di masyarakat dengan cara memberikan pengalaman kepada siswa sejak dini untuk memecahkan masalah yang dihadapinya. Jika siswa di sekolah terbiasa untuk berhadapan dengan masalah dan terlatih untuk 
mampu memecahkannya maka ketika mereka berada di masyarakat mereka juga akan mampu memecahkan masalah yang dihadapinya.

Sukmadinata (2008) mengungkapkan beberapa ciri dari desain kurikulum rekonstruksi sosial sebagai berikut: 1) menghadapkan siswa pada ancaman/hambatan/tantangan di bidang studi sosial yang kemudian didekati dari berbagai bidang ilmu; 2) pembelajaran difokuskan pada masalah sosial yang mendesak; 3) organisasi kurikulum disusun dalam sebuah masalah/tema yang dijabarkan dalam sejumlah topik yang kemudian didiskusikan.

Namun demikian, penerapan kurikulum kewirausahaan di SMP tidak akan murni menerapkan ketiga asumsi dari kurikulum rekonstruksi sosial, mengingat tekanannya tidak terbatas hanya kepada topik tapi juga kegiatan-kegiatan di sekolah yang menjadi sarana untuk membentuk jiwa kewirausahaan. Tantangan adalah kata kunci yang akan mewarnai aktivitas kurikulum kewirausahaan yang memerlukan pemecahan masalah segera sehingga siswa berani mengambil keputusan dengan risiko yang terukur. Esensi kurikulum subyek akademis yang dipadukan dengan kurikulum teknologis bisa dipakai untuk menanamkan nilai-nilai kewira-usahaan yang akan membentuk kompetensi wirausahawan.

Adapun hasil yang ingin dicapai dari pengembangan kurikulum kewirausahaan di tingkat SMP ini adalah membekali siswa dengan kemampuan untuk bisa hidup mandiri di masyarakat sehingga bisa memberikan kontribusi positif terhadap kemajuan bangsa. Bahan dari kurikulum kewirausahaan yang dikembangkan berdasarkan kepada ciri-ciri kewirausahaan yang berkenaan dengan sikap percaya diri, kreatif, berpikiran ke depan, berorientasi kepada hasil, kerja keras, bertanggung jawab, inovatif, jujur (orisinalitas). Nilai-nilai kewirausahaan di atas beberapa sudah terdapat dalam mata pelajaran seperti agama dan kewarganegaraan sehingga satu sama lain bisa saling menguatkan.

Berdasarkan ciri-ciri berpikir anak remaja yang bersifat hypotetico deducative, propotional thinking dan combinational thinking maka pembelajaran kewirausahaan lebih tepat jika dilakukan dengan menggunakan kegiatan belajar aktif melalui berbagai situasi yang menuntut pemecahan masalah. Oleh karena itu, metode yang digunakan dalam kurikulum kewirausahaan ini lebih berorientasi pada problem solving, demonstrasi, dan praktik.

Dengan metode di atas, siswa tidak hanya dituntut tahu tapi mereka juga dituntut untuk bisa menerapkan apa yang telah diketahuinya. Selanjutnya untuk kegiatan evaluasi bisa dilakukan dengan menilai sejauhmana siswa mampu menyerap dan menerapkan nilai-nilai kewirausahaan dalam memecahkan masalah, teknik yang digunakan bisa dilakukan melalui kegiatan wawancara dan observasi yang dilakukan oleh guru dengan melibatkan siswa.

\section{Simpulan dan Saran Simpulan}

Berdasarkan rumusan masalah dalam penulisan makalah ini maka ditarik simpulan sebagai berikut. Pertama, definisi kurikulum yang digunakan dalam menyusun kurikulum kewirausahaan ini adalah kegiatan-kegiatan di sekolah yang memberikan kesempatan kepada siswa untuk memperoleh pengalaman dalam menyerap dan menerapkan nilai-nilai kewirausahaan. Kedua, landasan pengembangan kurikulum kewirausahaan adalah budaya tolong-menolong, gotong rotong, dan kekeluargaan (landasan filosofis), perkembangan anak (landasan psikologis), pengangguran dan pendapatan perkapita (landasan sosiologis) dan bentuk organisasi kurikulum yang terintegrasi dalam setiap pengalaman belajar siswa di sekolah (landasan organisatoris). Ketiga, desain kurikulum yang digunakan dalam mengembangkan kurikulum kewirausahaan ini adalah desain kurikulum rekonstruksi sosial yang dipadukan dengan kurikulum subyek akademis dan kompetensi (teknologis); Keempat, muatan kurikulum kewirausahaan adalah nilai-nilai kewirausahaan yang perlu dikuasai oleh siswa yaitu percaya diri, kreatif, berpikiran ke depan, berorientasi kepada hasil, kerja keras, ber-tanggung jawab, inovatif dan jujur.

\section{Saran}

Mengacu pada simpulan, disarankan agar: 1) dikembangkan operasional berkenaan dengan berbagai definisi kurikulum kewirausahaan yang bisa diterapkan di sekolah, misalnya saja 
mengembangkannya dalam bentuk program pengajaran di sekolah, mengembangkannya sebagai usaha pihak sekolah untuk menghadirkan iklim kewirausahaan di lingkungan sekolah; 2) Dalam rangka mengembangkan landasan kurikulum kewirausahaan maka perlu dilakukan dengan melibatkan banyak pihak berkaitan dengan perumusan landasan filosofis, psikologis, sosiologis, dan organisatoris sehingga bisa dihasilkan landasan pengembangan kurikulum kewirausahaan yang kokoh; 3) dikembangkan model-model pengembangan kurikulum kewirausahaan yang lain, seperti model humanistik, subyek akademis sehingga bisa dijadikan perbandingan antara model yang satu dengan model yang lainnya; 4) dilakukan penggalian secara lebih seksama akan nilai-nilai kewirausahaan yang ada agar penerapannya bisa lebih sesuai dengan situasi dan kondisi lingkungan di mana siswa itu berada.

\section{Pustaka Acuan}

Alberty, Harold B., dan Elsie J. Alberty. 1965. Reorganizing the High-School Curriculum, New York : The Macmillan Company.

Antaranews.com. 2011. "Menkop: Jumlah Wirausahawan Masih Rendah", (online), (http:// www.antaranews.com/berita/247821/menkop-jumlah-wirausahawan-masih-rendah, diakses tanggal 12 Juni 2011).

Departemen Pendidikan Nasional. 2009. Rencana Strategis Departemen Pendidikan Nasional 20102014. Jakarta : Departemen Pendidikan Nasional.

Flavell, J. H. 1963. The developmental psychology of Jean Piaget. New York: D.Van Nostrand.

Henderson, James G. dan Richard D. Hawthrone. 2000. Transformative Curriculum Leadership. New Jersey : Prentice Hall.

Hermana, Budi. 2008. "Pengertian dan Teori Kewirausahaan", (online), ( http:// nustaffsite.gunadarma.ac.id/blog/bhermana/2008/04/05/sejarah-dan-teori-kewirausahaan/, diakses tanggal 12 Juni 2011).

Kompas.com. 2010. "Penganggur Akademik Dua Juta Orang", (online), (http://edukasi.kompas.com/ read/2010/09/27/09481825/Penganggur.Akademik.Dua.Juta.Orang, diakses tanggal 12 Juni 2011).

Krug, Edward A. 1960. Curriciculum Planning, Harper and Brothers, New York.

Lucas, William. 2007. Testing a Causal Model for the Development of Enterpreneurial Intention in Singapore, Regional Frontiers of Enterpreuneurship Research, (pdf), (www.swinburne.edu.au/lib/ir/ onlineconferences/.../lucas_summary_p134.pdf, diakses tanggal 12 Juni 2011).

Lupiyoadi, Rambat dan Jero Wacik. 1998. Wawasan Kewirausahaan : Cara Mudah Menjadi Wirausaha. Jakarta: Lembaga Penerbit Fakultas Ekonomi Universitas Indonesia.

Nasution, S. 2006. Asas-asas Kurikulum. Jakarta: Bumi Aksara.

Putra. 2008. "Definisi Kewirausahaan (Enterprenuership) Menurut Para Ahli", (online), ( http:// putracenter.net/2008/12/23/definisi-kewirausahaan-entrepreneurship-menurut-para-ahli/, diakses tanggal 12 Juni 2011).

Permana, Johar dan Darma Kesuma. 2008. Kewirausahaan dalam Pendidikan, Bandung : Alfabeta.

Ragan William, B. 1955. Modern Elementary Curriculum, The Dryden Press, Inc.

Saylor, J. Galen dan William M. Alexander. 1981. Curriculum Planning for Better Teaching and Learning, Fourth Edition, New York : Holt, Rinehart and Winston.

Smith, B. Othanel, 1956. Fundamentals of Curriculum Development, New York Yonker-on-Hudson, American Book Company.

Suderadjat, Hari. 2010. Bahan Kuliah Manajemen Kurikulum Pendidikan Dasar, Bandung : Pascasarjana Uninus.

Sukmadinata S., Nana. 2008. Pengembangan Kurikulum Teori dan Praktek, Bandung : Remaja Rosdakarya. 
Yudha Nata Saputra, Pengembangan Kurikulum Kewirausahaan di Sekolah Menengah Pertama

Susanti, Benny dan Sri Hermawati. 2008. "Kewirausahaan", (pdf), ( http:// entrepreneur.gunadarma.ac.id/e-learning/.../039 Kewirausahaan.pdf, diakses tanggal 12 Juni 2011).

Undang-Undang Dasar 1945 (Amandemen). 2009. Yogyakarta : Pustaka Grhatama.

Wardoyo, HP. 2008. "Ruang Lingkup dan Proses Terbentuknya Kewirausahaan", (pdf), (http:// wardoyo.staff.gunadarma.ac.id/Downloads/folder/0.0, diakses tanggal 12 Juni 2011). 